\title{
Building Entrepreneurial University: Case from HEI's in Indonesia
}

\author{
Eko Sakapurnama*, Martani Huseini, Pantius D Soeling \\ Department of Business Administration, Faculty of Administrative, University of Indonesia, Depok, Indonesia
}

Received October 8, 2019; Revised November 5, 2019; Accepted November 12, 2019

Copyright $\bigcirc 2019$ by authors, all rights reserved. Authors agree that this article remains permanently open access under the terms of the Creative Commons Attribution License 4.0 International License

\begin{abstract}
The trend of knowledge-based economy gives awareness that university governance must transform from research university to entrepreneurial university. This study aims to analyze how Bandung Institute of Technology (ITB), as one of the Higher Education Institution (HEI) in Indonesia, has a strategic plan to become an entrepreneurial university (EU). The Entrepreneurial University is defined as a university that uses natural incubators which provide a support structure for lecturers and students to start new, intellectual and commercial ventures. The method of this research is qualitative approach through in-depth interview and studying literature of secondary data. The results of this study indicate that the ITB's commitment and vision are crucial to building an entrepreneurial culture or atmosphere within the framework of the university's tridarma. In addition, the challenges that arise are at the macro level, where government regulations related to state-autonomous higher education are policies that must be adapted to the needs of ITB towards the EU.
\end{abstract}

Keywords Entrepreneurial University, Higher Education, Knowledge-based Economy, University Governance

\section{Introduction}

It is undoubtedly that universities as the centers of science often create various innovations and are considered to be agents that changed the civilization of a country (Philpott, et al., 2011; Fayolle and Redford, 2014). Universities are considered as the engines of development in a nation's development process (OECD, 2009). Some research results showed that in the last twenty years, the global environment has undergone changes that are relevant to the role of universities, including knowledge-based economy (Etkowitz,2004; Sporn,2001) and also how higher education must transform its curriculum to create students with the global readiness mindset (Huseini, Sakapurnama, Kusumastuti, 2018). Description from Powell and Snellman (2004) regarding knowledge-based economy could be interpreted as production and service processes based on scientific activities that are intensive in creating both technical and scientific excellence where the key component of a knowledge-based economy is greater dependence on intellectual abilities than physical input or natural resources.

The development of this knowledge-based economy, positioning knowledge as the main source of excellence or competitiveness and economic growth of the nation and the role of a university as a central institution that becomes the driving force for direct economic growth of a country in the future (Mohrman, Ma, Baker, 2008; Etzkowitz, 2004; Huggins, John, and Upton, 2008; OECD, 2009). Knowledge created by higher education is one of the intangible resources for organizations that will encourage sustainable excellence (Grant, 1996). Therefore, the traditional or maybe research universities are becoming obsolete and it is being transformed to entrepreneurial university.

In managing universities in Indonesia, the Government through the Ministry of Research, Technology and Higher Education refers to Law Number 12 of 2012 on Higher Education. Higher Education is a level of education following secondary education that includes diploma programs, undergraduate programs, master programs, doctoral programs, and professional programs, as well as specialist programs, provided by tertiary education institutions based on Indonesian culture. Furthermore, the government divides PTN (state universities) status by referring to Law No. 12 of 2012 Article 65 and Government Regulation No. 4 of 2014 Article 27 that divides the pattern of management of State Universities into (a) PTNs with a pattern of state financial management in general or recognized by work unit of PTN or PTN with 
PNBP pattern (Non-Tax State Revenue); (b) PTN with the pattern of financial management of public service agencies or PTN-BLU; (c) PTN as an state-autonomous university or PTN-BH.

Other aspects that are driving the change of universities which previously focused solely on scientific development, but since government incentive in financing higher education has decreased, requires universities to find other funding sources such as those in the United States and Great Britain (Lyall and Sell, 2006; Gibb and Haskins, 2013). There is commercialization on higher education, where there is a change from public universities to private universities as the impact (Lyall and Sell, 2006).

Some scholars explained that current universities should make adjustments to the learning model as a result of dynamic changes from the external environment (Sakapurnama, Huseini, Soeling, 2019). The transformation of universities which is currently still regarded as an institution of traditional "ivory towers" where the usefulness of science and knowledge has a distance from reality in society that must be changed (Scharmer, 2018).

Responding to various dynamic changes in the environment and trends in the future, there is a paradigm shift (shifting paradigm) in the learning process where universities must be able to innovate superiorly. It leads to the emergence of entrepreneurial universities or colleges that have governance and entrepreneurial orientation, which are considered more compatible for universities to be able to compete in the present and in the future (Clark, 2003; Etzkowitz, 2003; Etkowitz, 2004; Kirby, 2006, Gibbs and Haskins, 2013; Fayolle and Redford, 2014). Thus, the purpose of this research is to explain how ITB as one of the state-autonomus University in Indonesia has taken strategic steps to build the EU, so that it can become a model for similar institutions.

\section{Materials and Methods}

The paradigm used in this research is the post positivism paradigm, as this research will explain the pattern/ form of entrepreneurial university in the context of public universities in Indonesia through various quantitative data collection from literature studies and qualitative methods such as interviews and participant observation (Creswell, 2008). The definition of Entrepreneurial University (EU) is derived from various scholars. The concept EU was coined for the first time by Etzkowitz (1983) that explained the university which is seeking new funding such as from patents, research funded by contract, as well as building partnership with private company (OECD, 2009).

Moreover, Clark (1998) defines that EU is university which has attempts to innovate in how to run a business, create shift of substantial organizational characters, and become a university that is an important actor in their own terms. In n modern era, in which universities become the center of economic knowledge, entrepreneurship-oriented universities are perceived as the central power that promotes innovation, creativity, and economic growth (Audretsch, et al., 2006). Etzkowitz (2003) suggested that just like traditional process undertaken by each university by training their students to be competitive in life after campus, Entrepreneurial University is a natural incubator, as it provides support structure for teachers and students to start a new business.

According to Gibb (2013, in Coyle, Gibb and Haskins, 2013), challenges that emerge in the term 'entrepreneurial university' are the concept of entrepreneurship for universities, i.e. entrepreneurial university is associated with the efforts to undertake commercialization of various intellectual properties which are the results of various innovations, patents, and research conducted by lecturers through transformation of technology, incubator, and science parks. Whereas, a wider concept can also be implemented.

Some concepts were also used to support the synthesis of thinking in including the Entrepreneurial University model from Etzkowitz (2008), which is shown in the Figure 1 below. There are two dimensions which are exogenous factors that comprise the external condition pushing the university to change, for example, from the government regulation reflecting top-down approach. Another one is endogenous factor that contains how universities internally consolidate and pull to change to meet the demand. Both factors are constructing the more entrepreneurial-oriented higher education institution and pursuing the collaboration among three sectors (academic, business, government) that called triple-helix.

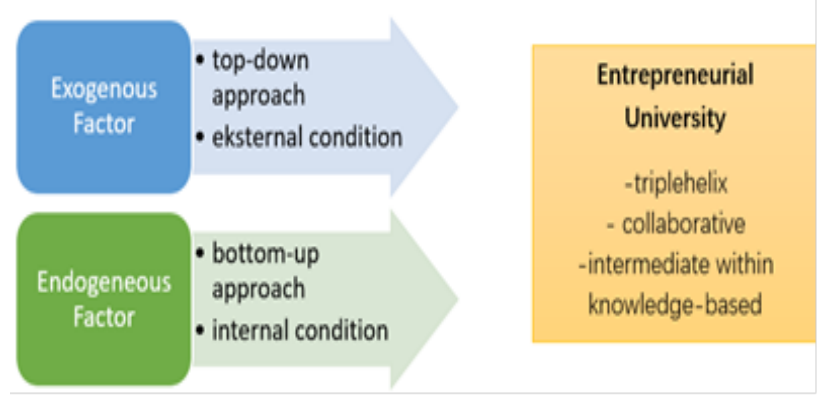

Source: Etzkowitz, et al (2008), Image processed by researchers (2019)

Figure 1. University Entrepreneurial Model

\subsection{Research Framework}

Building upon the entrepreneurial university literature, researchers develop a research framework that comprises ITB is entrepreneurial university yet or not. Figure 2 describe the framework that use to analyse this study derives from the theory explained recently. 


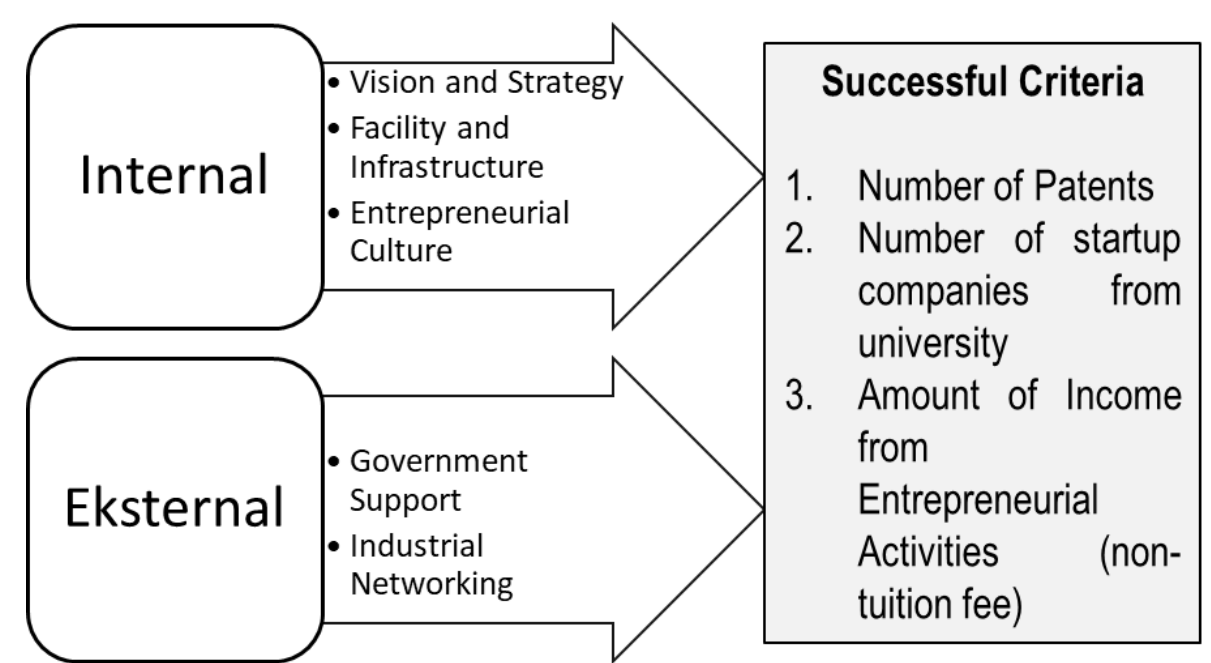

Source: data processed by researchers (2019)

Figure 2. Research Framework

\subsection{Data Collection}

The question in this study is how the capacity of Entrepreneurial University in ITB will be answered by using qualitative methods through in-depth interviews with university leaders. The key informants interviewed are explained in the following table:

Table 1. List of Key Informant

\begin{tabular}{|c|c|c|c|}
\hline No & Name & Position & Information Target \\
\hline 1 & $\begin{array}{l}\text { Prof. Dr. Wawan Gunawan } \\
\text { A. Kadir MS }\end{array}$ & $\begin{array}{l}\text { Vice Rector of Finance, Planning and } \\
\text { Development }\end{array}$ & $\begin{array}{l}\text { To obtain information on ITB's strategy in } \\
\text { heading to the EU }\end{array}$ \\
\hline 2 & $\begin{array}{l}\text { Prof. Dr. Ir.Bambang } \\
\text { Riyanto Trilaksono }\end{array}$ & $\begin{array}{l}\text { Vice Rector of Research, Innovation, and } \\
\text { Partnership }\end{array}$ & $\begin{array}{l}\text { To obtain information about ITB's strategy in } \\
\text { heading to the EU and implementation in } \\
\text { business development units in ITB. }\end{array}$ \\
\hline 3 & $\begin{array}{l}\text { Dr.Ir. Sigit Puji Santosa } \\
\text { MSME }\end{array}$ & $\begin{array}{l}\text { Head of Institute for Innovation and } \\
\text { Entrepreneurship Development ITB } \\
\text { (LPIK) }\end{array}$ & $\begin{array}{l}\text { Strategy for innovation development and } \\
\text { entrepreneurship in ITB. }\end{array}$ \\
\hline 4 & Sugeng Rahardjo & $\begin{array}{l}\text { President Director \& Chief Executive } \\
\text { Officer LAPI ITB }\end{array}$ & $\begin{array}{l}\text { Implementation in business development unit } \\
\text { in ITB. }\end{array}$ \\
\hline 5 & $\begin{array}{l}\text { Rofiq Iqbal, S. T, M. Eng, } \\
\text { Ph. D }\end{array}$ & $\begin{array}{l}\text { Secretary of LPIK Innovation Division, } \\
\text { ITB }\end{array}$ & $\begin{array}{l}\text { Implementation of innovation and } \\
\text { entrepreneurship development in ITB }\end{array}$ \\
\hline 6 & Aprillia Annisa, S.I.P., MBA & $\begin{array}{l}\text { Expert Assistant to LPIK Industrial and } \\
\text { Business Incubator Division, ITB }\end{array}$ & $\begin{array}{l}\text { Implementation development of innovation } \\
\text { and entrepreneurship in ITB }\end{array}$ \\
\hline 7 & $\begin{array}{l}\text { Dr. Totok Prasetyo, B.Eng., } \\
\text { M.T. }\end{array}$ & $\begin{array}{l}\text { Director of Higher Education } \\
\text { Institutional Development, Ministry of } \\
\text { Research, Technology and HEI }\end{array}$ & $\begin{array}{lll}\text { Government policy } & \text { support for } \\
\text { Entrepreneurial University } & & \end{array}$ \\
\hline
\end{tabular}




\subsection{The History of ITB}

The history of ITB began with the establishment of the Technische Hogeschool (THS) which was established on July 3, 1920, which was the first technical college in the Indies. Furthermore, THS was closed during the Japanese occupation and then reopened after the Proclamation era with the name of the College of Engineering (STT) in Yogyakarta, but was later closed due to Dutch Military Aggression. On January 21, 1946, the Faculty of Engineering which was part of the Universiteit van Indonesia (now Universitas Indonesia) was re-established in Bandung. Finally, ITB was officially formed on March 2, 1959 which was a combination of the Faculty of Engineering and the Faculty of Science and Natural Sciences, University of Indonesia at the THS campus in Bandung (Kartodiwirio, 2006).

\subsection{ITB's Vision and Strategy}

The idea of becoming an entrepreneurial university was originally planned since 2014 by Prof. Dr. Ir. Kadarsah Suryadi, DEA as Rector of ITB (Ardiansyah, 2017). In its journey, ITB has executed the TriDharma College by supporting research, innovation and entrepreneurship which have an impact on society through technology and built synergy among universities, industry, government and community (Kadarsyah, within ITB, 2018).
Currently ITB has transformed from Teaching University into research university and then into entrepreneurial university, as delivered by the Deputy of Finance, Planning, and development.

"If we are translating entrepreneurial university the first thing we do is to be excellent in the teaching. Second,it's to be excellent in the research. And the last is, excelled in innovation, which has the understanding that the technology generated by ITB can be useful directly for the community. Also having or not having the economic value depends on the atmosphere and the situation as well. It is in 2020. Which is 5 years in the strategic plan where there is a major target"

(interview with Kadir, 2019)

The explanation is in line with the 2016-2020 ITB strategic plan document, and it is to become an entrepreneurial university, ITB has three strategies. First is to become a world-class university. ITB can produce graduates who have very high readiness to work in the working world, in other words ITB must demonstrate excellence in teaching and learning. Second is that becoming a research-based entrepreneur college where ITB produces research for the development of science and technology that is needed for nation-building, so that ITB must have excellence in research.

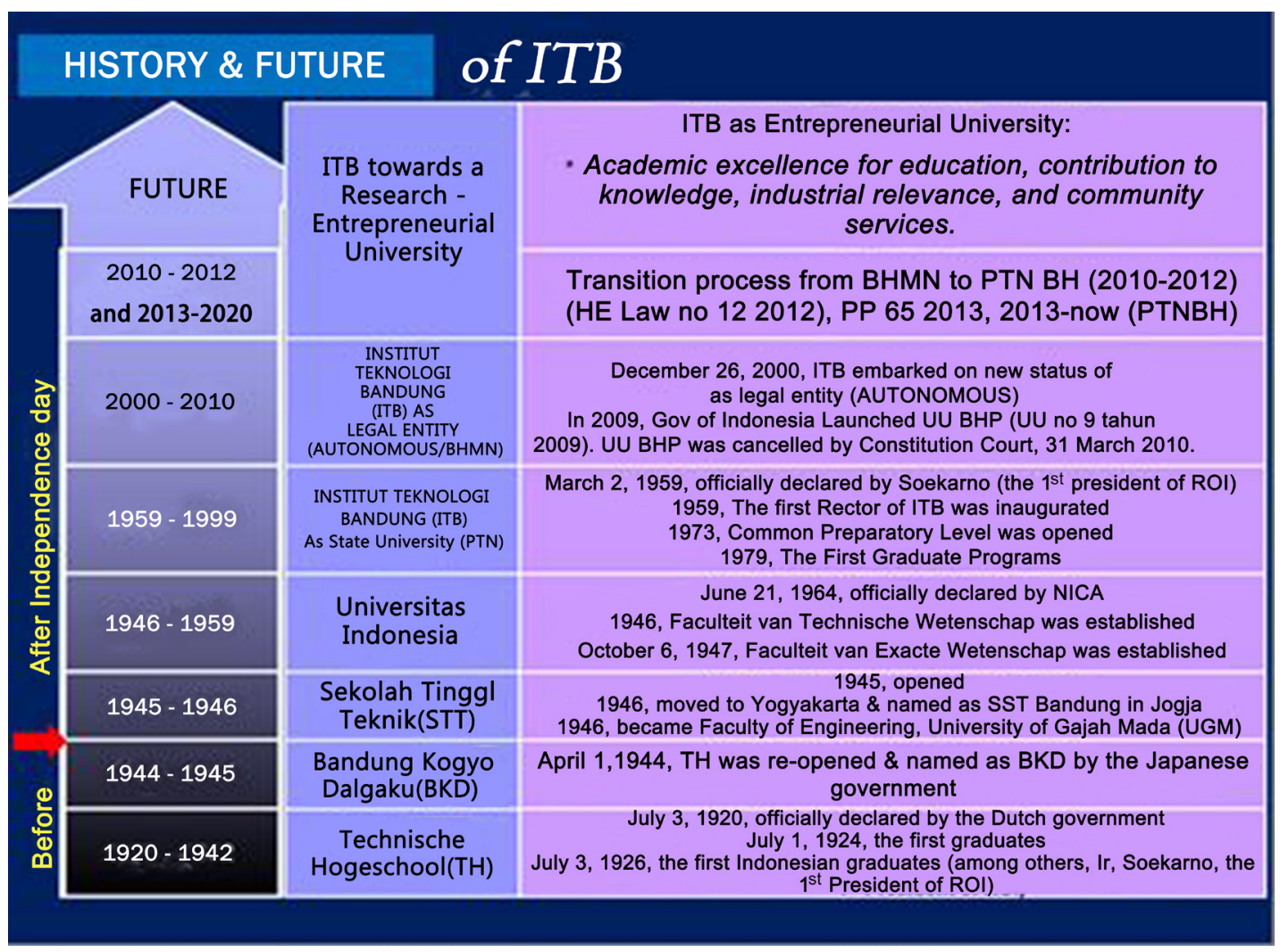

Source: ITB (2018)

Figure 3. History of Bandung Institute of Technology (ITB) 
The third strategic goal is ITB become a university that contributes to increasing competitiveness and achieving national independence. ITB is expected to be able to produce products or innovations in any form that can directly benefit the public, called excellence in innovation. These three aspects are the reflection of realization from the Tri Dharma of Higher Education which is practiced at ITB.

In the level of strategic implementation, in order to realize the achievement of ITB excellence in teaching and learning, in addition to fulfilling accreditation from National Higher Education Accreditation Agency (BAN-PT) at the national level, ITB also seeks to accredit teaching methods from international accreditation institutions, as stated by the Vice Chancellor for Finance, The following planning and development:

"Excellent teaching is the accreditation done by others not by ourselves, which determines that our education and teaching process is superior. We will ask assistance from others who are independent. If we think that Ristekdikti is not independent, this BAN-PT is also quite so. So we are focusing on international accreditation. We are immediately chasing for the engineering to ABET. For those who are focusing in science and engineering there are some who reach it to. ASSIN. Architecture to Korea. Then there is also the business school and management going to Japan. Chemistry if I'm not mistaken, to England ... ... In total, 38 out of 48 study programs are internationally accredited."

(interview with Wawan Gunawan Kadir, 2019)

The second strategic goal is to realize excellence in research, ITB composes 7 (seven) areas of research focus according to Decree No. SA. 20 / SK / K01-SA / 2010 to produce the superior research outputs described in figure 4.

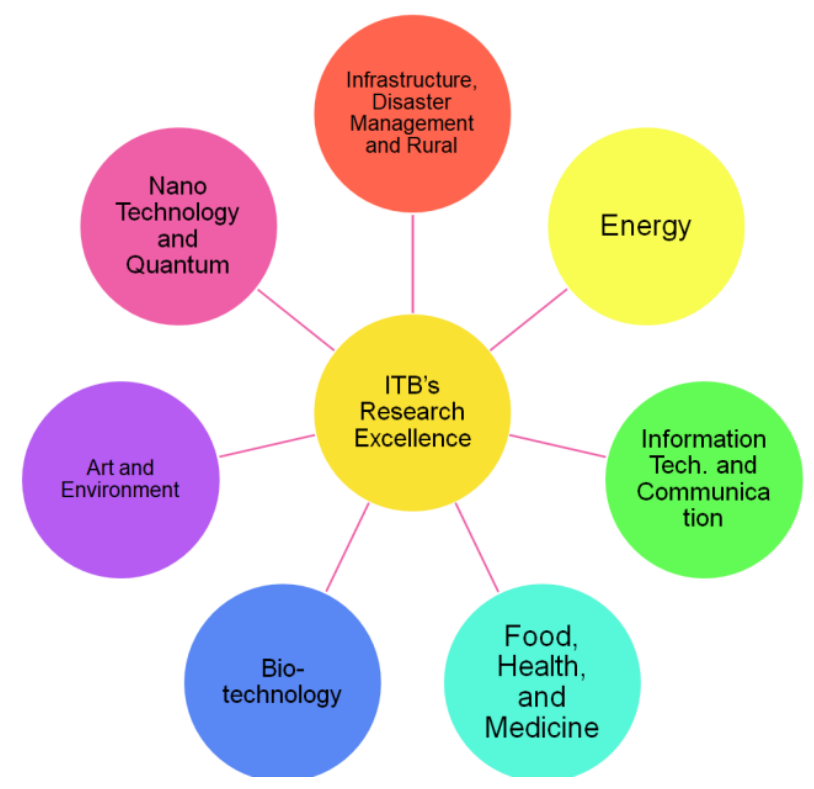

Source: data processed by researchers (2019)

Figure 4. ITB's Research Exellence

\subsection{ITB's Facility and Infrastructure}

Furthermore, to realize the third strategic goal, ITB optimizes the Institute for Innovation and Entrepreneurship Development (LPIK) to become a motor for achieving excellence in innovation that is oriented to entrepreneur universities.

LPIK ITB also has several programs to facilitate entrepreneur activities for staff and students. They grant research innovation for the inventor to stimulate invention. Furthermore, ITB serves both pre-incubation and incubation programs for academicians and students who run business startup. To enhance entrepreneurial skills and mindset of student and staff, LPIK also delivers mentoring, coaching and also training entrepreneurship workshop. The pitching session is ITB CEO Summit. Every year the ITB CEO Summit program is held to disseminate ITB research products with the industry (see figure 5). 


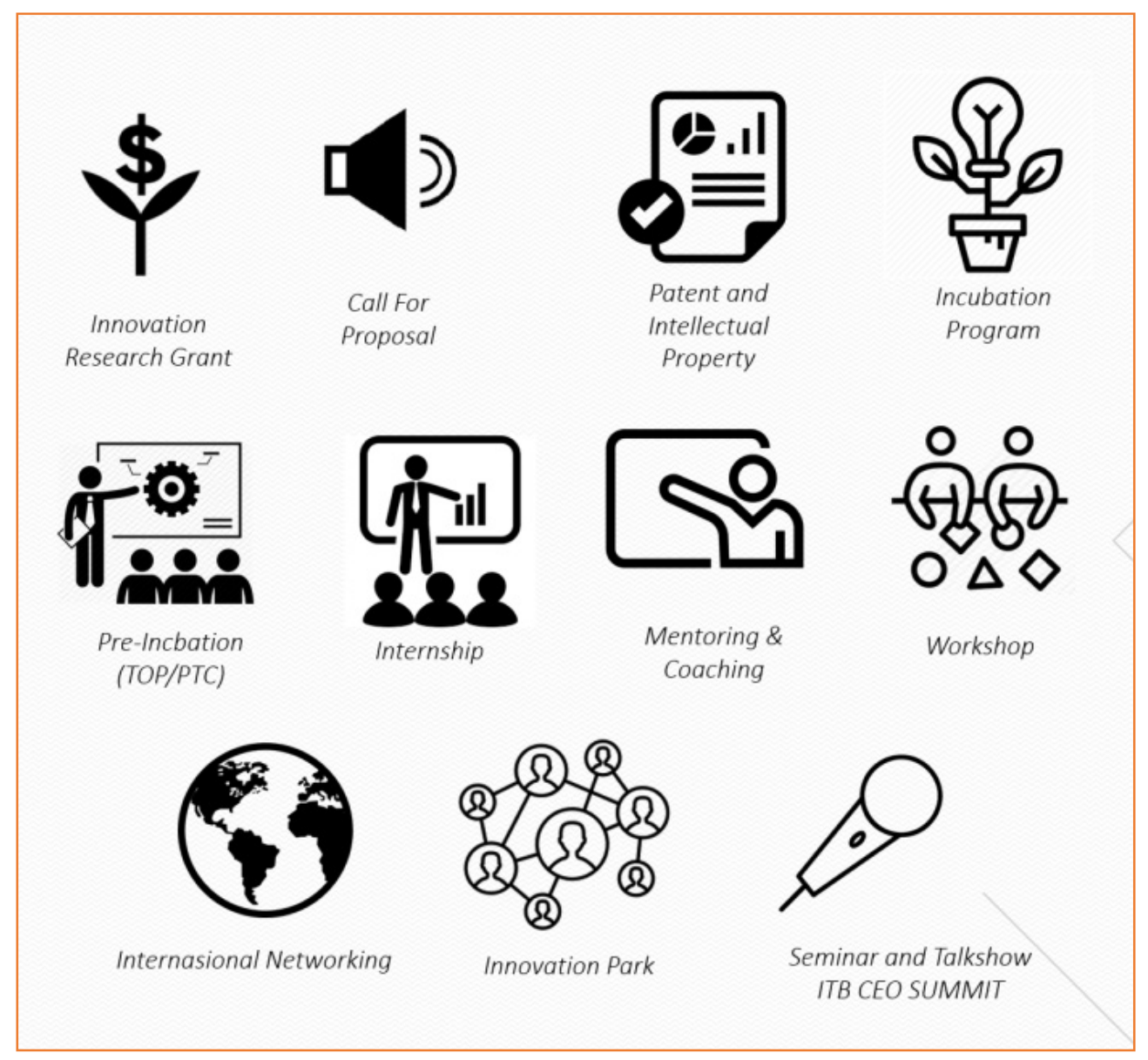

Source: ITB (2019)

Figure 5. LPIK ITB Program Facilitation

\subsection{Entrepreneurial Culture}

To build an entrepreneurial spirit, ITB seeks to build ecosystems that support entrepreneurial activities. LPIK builds an innovation ecosystem (see figure 6) that synergizes between various patents and innovations of ITB, whose industrial collaboration realizes the downstream research, as delivered by the Head of LPIK ITB, as follows:

"So, we have translated the entrepreneur university in the term of building the ecosystems, strong one.

Between the innovation ecosystem and the commercialization industrial ecosystem, that's what we build. As such, we don't need to worry about budget problem, because when we run industrial cooperation we will inevitably have revenue from funds coming from the industry, or from partners to LPIK ...

(interviewed with Sigit Puji Santosa, 2019)

LPIK's Vision is to become a reliable and reputable institution, in an effort to bring Indonesian society into a prosperous nation by advancing the competitiveness of Indonesia industries and human resources. Thus, the missions are: (1) to conduct mediation and coordination within the framework of innovative fundraising through business and industry partnership; (2) to guide the development and changes made by the community through high quality innovation and entrepreneurship development activities, directly beneficial, and have a significant impact on improving welfare of the people, nation and state. (ITB, 2018)

The synergy built in the business processes within ITB is carried out through an organizational design framework in a coordinative scope. The Institute for Research and Community Service (LPPM) ITB as the work unit that manages research activities and community service and LPIK is in one area under the coordination of the Vice Chancellor for Research, Innovation and Partnership.

Sigit explained that when ITB lecturers conducted research, LPIK conducted a search for potential research to be carried out downstream and it measured in technology readiness level from 5 to 9 . Then for the commercialization process, ITB uses its strategic business unit called Rekacipta Innovation ITB.

"Now that we have access to TRL 4 or 5, we have already started looking for industrial maps. Even LPIK also received substantial funding from ITB to provide funding to conduct ITB innovation mastery research. We oblige them to work with the Ministry of Industry. How 
to do this? What is the strategy? What is the execution like?

(interview with Sigit Puji Santosa, 2019)

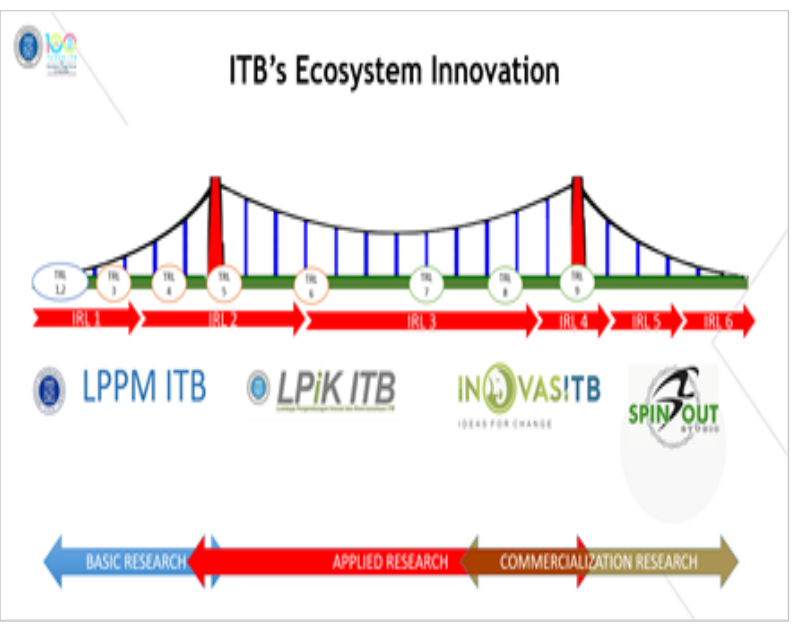

Source: LPIK ITB (2019)

Figure 6. Value Chain of ITB's Research Commercialization

The Value Chain of ITB's Research Commercialization is continuing from the very beginning basic research (from TRL 1-4) handled by Research and Community Engagement Unit (LPPM). Then, if the invention has potentially economic value, it continues by LPIK (research with TRL 5-8) with the output whether prototype product is with intellectual property or patent.

The LPIK will develop until commercialization was assisted by ITB's holding company, called PT. Rekacipta Inovasi ITB, and incubate the startup, so that it becomes a mature company that is ready to spin off.

\subsection{Government Policy and Industrial Support}

From the external dimension, as explained in the previous paragraph, in accordance with the applicable policies, Law Number 12 of 2012, article 65, the Indonesia Government gives ITB the authority, one of which is the authority to establish business entities and develop endowments and the right to manage funds independently, transparently and accountably.

The authority, often feared to be a commercialization of higher education in Indonesia, where as a state autonomous university (PTNBH) it will increase the student tuition fee. Moreover Ministry of Higher Education, still has policy whether PTNBH must conduct as research university with heavily publication rather than as an entrepreneurial university that more heavily gives impact and innovation to the society as stated below:

"We are still focusing how PTNBH become research university, so they can produce more publication in Scopus in order to achieve World University ranking better."

(interviewed with Totok Prasetyo, 2018)
From the industrial networking support, ITB has an excellent opportunity that many companies support ITB research and innovation from state-ownd enterprise (example PT Pertamina, PT INKA) and private companies. Moreover, ITB also develops international networking from various organizations (such as: Plug and Play (Silicon Valley); National Enterprise Network (India); NUS Enterprise - Block 71; Sungkyunkwan University (South Korea); EU - BIC (European Business Incubation Centre) and ASEAN Startup Network to support the ITB becoming Entrepreneurial University.

Based on the model of analysis, ITB has built its institute as an entrepreneurial university. From the analysis above, we can conclude that various dimensions have been met, even though government support has not yet led to it, which is shown on table below:

Table 2. ITB's Readiness as Entrepreneurial University

\begin{tabular}{|c|c|c|}
\hline Dimension & Indicators & Good \\
\hline \multirow{4}{*}{ Internal } & Vision and Strategy & Fair \\
\cline { 2 - 4 } & $\begin{array}{r}\text { Facility and } \\
\text { Infrastructure }\end{array}$ & Fair \\
\cline { 2 - 3 } & $\begin{array}{c}\text { Entrepreneurial } \\
\text { Culture }\end{array}$ & Not Enough \\
\hline \multirow{2}{*}{ External } & $\begin{array}{r}\text { Government } \\
\text { Support }\end{array}$ & Fair \\
\cline { 2 - 3 } & $\begin{array}{c}\text { Industrial } \\
\text { Networking }\end{array}$ \\
\hline
\end{tabular}

\subsection{Successful Criteria}

Based on literature and study document, in the last five years from 2014-2019, there are 237 patent submission, 43 patent granted and 57 IP's. ITB also has 112 business startup and 25 companies successfully invested by investor through spin-off mechanism (data as per 22 July 2019). ITB usually invites some venture capital and conducts pitching session with the investor club for instance: Lintasarta, Mandiri Capital, BNI Venture Capital, East Venture, Grab Venture, Bukalapak, Shell Venture.

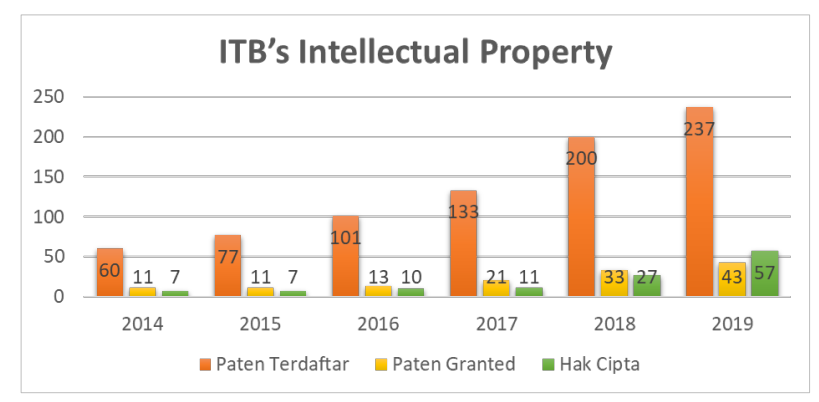

Source: LPIK ITB (2019)

Figure 7. Number of ITB's IP

In Figure 7, after the Chancellor of ITB stated its strategy to become Entrepreneurial University in 2014, there are tremendous incremental numbers of patents. It increases almost four times from 60 patent in 2014 to 237 
patents in 2019.

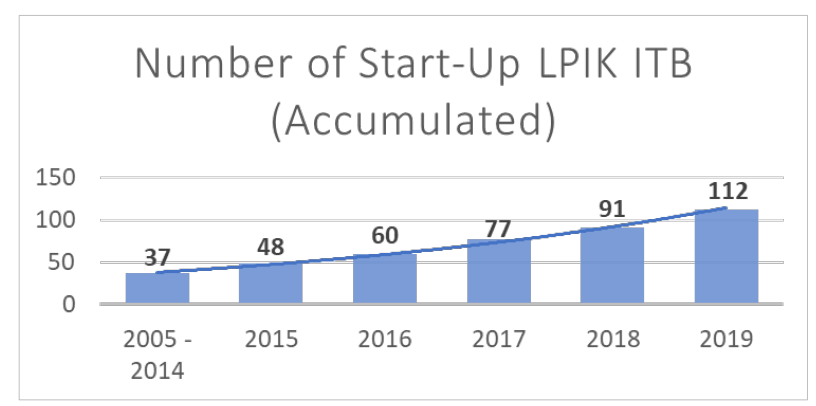

Source: LPIK ITB (2019)

Figure 8. Number of ITB's Startup

The number of start-up company from ITB also has dramatically increased. From only 37 startups in 2014, it nearly triple to 112 startups as per July 2019. The statistic data have proven that the ITB has on the right track in building as entrepreneurial university.

\section{Conclusions}

It is believed that ITB as an entrepreneurial university tries to conduct the continuous improvement of ITB's contribution in shaping the national competitiveness through research and innovation. In search of excellence, ITB created entrepreneurial ecosystem in integrating campus life through LPIK ITB, government and also private sectors.

\section{Acknowledgements}

This research is part of my thesis dissertation as $\mathrm{PhD}$ Student in Faculty of Administrative Science Universitas Indonesia and also as an output for my research granted by Ministry of Research, Technology and Higher Education, Republic of Indonesia

\section{REFERENCES}

[1] Adriennawati, Bianca., 2016. Status PTN Badan Hukum Picu Komersialisasi Pendidikan Tinggi, [online]: http://sua ramahasiswa.com/status-ptn-badan-hukum-picu-komersiali sasi-pendidikan-tinggi/

[2] Audretsch, D. B., Lehmann, E., \& Warning, S. 2005. University Spillovers and New Firm Location. Research Policy, 34(7), 113-1122

[3] Clark, B.R., 2003. Sustaining Change in Universities: Continues in Case Studies and Concepts, Tertiary Education and Management, 9 (2), p.99-116

[4] Etzkowitz, H. 2003, Research groups as 'quasi-firms': the invention of the entrepreneurial university, Research Policy
Volume 32, Issue 1, January 2003, Pages 109-121, [online]: https://www.sciencedirect.com/science/article/pii/S004873 3302000094

[5] Etzkowitz, H. 2004. The evolution of Entreprenerial University, International Journal of Technology and Globalisation, 1 (1), p. 64-77

[6] Fayolle, Alain., Redford, Dana T. 2014. Handbook on the Entrepreneurial University, Edward Elgar Publishing Limited, Cheltenham, UK

[7] Gibbs, A Allan., Haskins, Gay. 2013, The University of The Future an Entrepreneurial Stakeholder Learning Organisation?, Handbook of Research in Entrepreneurial Education Volume 4 - Entrepreneurial University Handbook, Edward Elgar, online[http://ncee.org.uk/wpcon tent/uploads/2014/06/ARTICLE_FINAL_FINAL_FINAL BOOK_VERSION_UNIVERSITY_OF_THE_FUTUR E.pdf]

[8] Huseini, M., Sakapurnama, E., \& Kusumastuti, R. (2017). Formulating learning method in higher education for global readiness. Turkish Online Journal of Educational Technology, 2017(November Special Issue IETC), 337-343

[9] Powell, Walter, W., Snellman, Kaisa., 2004. The Knowledge Economy, Annual Review Sociology, 30, pp. 199-220

[10] Kirby, D.A., 2006. Creating Entrepreneurial University in the UK: Applying Theory to Practice. Journal of Technology Transfer, 31, p.599-603.

[11] Lyall, C. Katherine., Sell, R, Kathleen., 2010. The De Facto Privatization of American Public Higher Education, Change: The Magazine of Higher Learning, Volume 38, Issue 1, [online]: http://www.tandfonline.com/doi/abs/10.3 200/CHNG.38.1.6-13?journalCode $=\mathrm{vchn} 20$

[12] OECD. 2009. Universities, Innovation and Entrepreneurship Criteria And Examples Of Good Practice

[13] Sakapurnama, Eko., Huseini, Martani, Soeling, PD., 2019. The Challenges In Higher Education Institutions In Indonesia: Are We Entrepreneurial University Yet?. Hasanuddin Economics and Business Review, Vol 2, No 3 (2019), [online]: http://pasca.unhas.ac.id/ojs/index.php/heb r/article/view/1680

[14] Scharmer, Otto. 2018. Education is the kindling of a flame: How to reinvent the 21 st-century university, [online] https://www.huffingtonpost.com/entry/education-is-the-kin dling-of-a-flame-how-to-reinvent us 5a4ffec5e4b0ee59d4 $1 \mathrm{c} 0 \mathrm{a} 9 \mathrm{f}$

[15] Sporn, B. 2001. Building Adaptive Universities, Emerging Organizational Forms Based on Experiences European and US Universities, Tertiary Education and Management, 7(2), pp. 121-134

[16] Yonvitner. 2017, Masih soal Otonomi PTN Badan Hukum, Media Indonesia, [online]: http://www.mediaindonesia.co $\mathrm{m} /$ news/read/103202/masih-soal-otonomi-ptn-badan-huku $\mathrm{m}-1 / 2017-05-04$ 